Journal of Humanities, Social and Management Sciences (JHSMS)

https:// doi.org/10.47264/idea.jhsms/1.1.3

Vol. 1, No. 1 (January-December 2020), 30-43

https://www.ideapublishers.org/index.php/jhsms

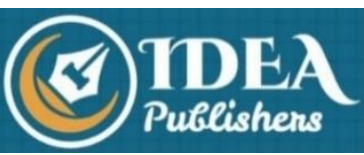

Research Article

\title{
Impact of Arab Spring on Egypt: An Analysis of Opportunities and Challenges
}

\author{
Amna Mahmood*, Sadia Wajid and Tatheer Zahra Sherazi \\ Department of Politics \& International Relations, International Islamic University, Islamabad, Pakistan. \\ * Corresponding Author Email: amna.mahmood@iiu.edu.pk
}

\begin{abstract}
Arab spring emerged as a unique phenomenon: not only that it surprised the world's policy makers, but it also started a debate in the academia about the reasons, motivations and dynamics of change and its explanations within the paradigms of existing theories of political change. This change was the result of political mobilization of certain new sectors of societies in Arab countries. The nature and direction of this change was no doubt different in different countries but it inspired the entire region as a domino effect. It left no option for all the authoritarian regimes in pre-dominantly Muslim Middle East but to opt for political reforms at least. Although the western powers welcomed Arab Spring at the beginning however this optimism eroded when the later developments proved that a democratic electoral process might produce governments, not entirely to the liking of the West. This paper examines; (a) the socio-political mobilization that proved to be the last blow to the Mubarak's dictatorship and formation of President Muhammad Morsi's elected government; (b) the post-2011 political dynamics in Egypt; (c) the implications of the rise of Islamists to power in Egypt for regional politics; and (d) the response of the western world towards Islamists power and 2011 mobilization.
\end{abstract}

Keywords: Arab Spring, Authoritarianism in Egypt, Uprising in Egypt, Democracy in Egypt, Islamists in Egypt.

How to Cite:

Mahmood, A., Wajid, S. \& Sherazi, T. Z. (2020). Impact of Arab Spring on Egypt: An Analysis of Opportunities and Challenges. Journal of Humanities, Social and Management Sciences (JHSMS), 1(1), 30-43. https://doi.org/10.47264/idea.jhsms/1.1.3

\section{Publisher's Note:}

IDEA PUBLISHERS (IDEA Journals Group) stands neutral regarding jurisdictional claims in the published maps and institutional affiliations.

\section{Copyright:}

(C) 2020 The Author(s), published by IDEA PUBLISHERS (IDEA Journals Group)

This is an Open Access article published under the Creative Commons Attribution-NonCommercial 4.0 International License (http://creativecommons.org/licenses/by-nc/4.0/) 


\section{Introduction}

The information revolution and effective role of the groups working on social networks created awareness among the Arab masses generally and in youth particularly, which was hard to imagine even a decade before. Coupled with the global wave of democratization, the mass uprising in many Arab Muslim states became a serious challenge to despots, ruling for decades. It actually transformed Tunisia, as a symbol of change in the Middle East. Egypt, was passing through the same process. The revolution has been transported to the other countries of the region. This paper examines the nature, process and dynamics of political change in Egypt. The political change in Egypt also influenced the direction of change in other Muslim countries. Secondly, being a US ally it has an important place in US foreign policy. Therefore, the US interests were also involved in the internal political changes in Egypt.

The revolution is the reflection of the host society. It can be inspired by the external influences, but cannot be dissociated from the social and cultural norms of that society in which it is carried on. Since the Egyptian society is overwhelmingly Muslim and 87 percent people give religion an important position in their lives ${ }^{1}$ therefore, any change which is moved from inside cannot be without its religious identity. Egyptian Muslim could be moderate and modernized but could not be secular in the Western sense. At the initial stage of the 2011 uprising, Western elites tried to direct Egyptians movement to introduce western styled democracy. This paradigm basically pushes for "top-down political reforms" rather than "bottom up overthrow" of the political and economic system of a country. However, it was against the demands of the Egyptian youth. They demanded democracy with the religion as an essential character (De Smet \& Matthies-Boon, 2013).

This study is limited to the period of Muhammad Morsi government. The first section of this paper examines the reasons for mass mobilization that stimulated the ouster of President Hosni Mubarak after 29 years. Second section deals with the political process of transformation of Egypt from an authoritarian to elected government; constitutional and institutional change; and role of military and judiciary. The third section of this paper explores the implications to the region due to the rise of Muslim Brotherhood (MB) to the power. The fourth section of the paper deals with the response of the US and the west towards the post-revolution changes and its implications. The last section briefly concludes the discussion.

\section{Internal Factors Responsible for Uprising}

The revolution of 2011 in Egypt sparked by the brutal death of Khaild Said in cold-blood, in Alexandria on $6^{\text {th }}$ June 2010 at the hands of security service officers in civies. That event led towards serious chaos on Tahrir square, Alexandria and in many other cities of Egypt. This was one of the immediate reasons, among other various longstanding issues. Despite the resignation of the Husni Mubarak, security forces failed to improve the law-and-order of the country and control street crimes, kidnappings, robberies as well as sexual harassment in the days of the uprising and afterwards (Londono, 2011). However, the major reason for this mass uprising was the long-standing discontentment towards the government policies, widespread corruption, financial crisis, unemployment, discriminatory attitude toward minorities. The whole anger was marked towards a corrupt non-representative authoritarian 
government, which was unable to address the problems of the people (Glassman \& Glickmen, 2011). The self-immolation of Muhammad Bouazizi in Tunisia became the turning point and started a new era of political mobilization in the Middle East (Times, 2011). ${ }^{2}$ This revolution was exported to the neighbouring Muslim countries torment with the common challenges across Middle East.

The case of Egypt is complex. The economic indicators were showing its economy in a better position than ever at the time of the uprising on $25^{\text {th }}$ January 2011. Its share in the world trade had increased triple times, GDP was growing 5-7 percent during 1990-2008 and direct foreign investment remained $\$ 46$ billion during the period of 2004-2009 (A Special Report on Egypt, 2010). Now the question is that if the economy was growing at such an impressive rate why economic discontentment was so high. The answer is that in comparative sense, the economic performance was impressive, but it could not come up to the expectation of the masses. Secondly, the development was uneven, leaving some areas totally deprived like Sinai and Upper Egypt. The gap between rich and poor was rising and the unemployment rate rose to 9.7 percent. This alienated the youth especially the university graduates from Mubarak's regime.

However, the revolution could not help to address the economic discontentment. Practically the economic indicators showed a decline because of political uncertainty. Further, the rapid growth of population created more than $2 / 3$ of the population under the age of 30 with either no jobs or underpaid jobs. After four years of revolution, investors were holding back and waiting for the appropriate environment and security situation. But, when a country moves from the dictatorial regime to democracy or vice versa the pace of economic change normally does not sustain. As the post-Mubarak transition has been uncertain, therefore, it was not easy to carry the economic reforms (Plumer, 2013).

Egypt was under despotic rulers with the support of a strong military since 1952. Despite mass protest and demand for more participation the constitution was amended to consolidate one man rule. Throughout Mubarak regime, the political landscape was limited to the National Democratic Party by having representation in the People's Assembly and Shura Council, which met with economic dislocations, political "de-liberalization" and Islamist movements (Beitler, 2003). The legislature was a showpiece. There was a ban on public demonstrations and any such effort was dealt with by excessive use of force like tear gas, rubber bullets and water cannons. These suppressions led to increasing protests, which became uncontrolled in 2011. It is estimated that the acts of protests in 2004 were 266 which became 630 in 2008 and became average 5 per day in 2010 (Calleya \& Wohlfeld, 2012). This shows the rising discontentment against the government.

Egypt was facing human rights abuse, media censorship along with discriminations against women, minority and labour classes. Persecutions of journalists and those involved in the protest had been a feature. According to an international report on religious freedom (USCIRF) Egypt was on watch list due to "systematic, ongoing, and egregious violations of religious freedom” (Human Rights First, 2011).

\section{Social Media and Uprising}

The censorship on conventional media and people's access to internet led to an unprecedented phenomenon, i.e., communication through social media to exchange messages for democracy 
and regime change (Taylor, 2011). Although the Egyptian Constitution was amended in 2005, but not to bring democracy rather to further strengthen one man's rule of Mubarak. The elections of the legislature were fraud followed by the deception in elections of 2010. Even Freedom of expression was fully curtailed by the state. Tahrir Square, a central place in Cairo was banned for any demonstration since 1981, with the rise of Mubarak as president of Egypt. This suffocation during the despotic rule of Mubarak for 29 years aliened the educated youth to the extent that they had designed groups on social media like: 'Egypt is not my mother.' All this happened with an unpresented pace without alarming government. When Mubarak regime tried to block internet resources, it was too late (Social Capital Blog, 2013).

There was a remarkable coordination on social media that millions of people turned out simultaneously for protest and Mubarak regime was caught in surprise. Around 250,000 people gathered at Tahrir Square of Cairo, the capital of Egypt, for what they call it the "day of rage" (UNDP, 2011) against the Mubarak regime. The fourteen days of demonstration resulted in bloody clashes between the pro and anti-Mubarak forces on the pattern of Tunisia. It was a consistent and long struggle by the common people started in January 2008 leading to Tahrir Square demonstrations in January 2011 (Baron, 2012). It was joined by all the factions of society, including liberals, Islamists, women and minorities, which finally instituted Mubarak to resign on 11 February, 2011.

\section{External Factors for Uprising}

Egypt was the pivotal actor for the United States (US) and this fact has a clear impact on its transitional road map during 2011 because of its regional policies, Egypt-Israel peace deal (1979), access to oil, leading intellectual role in the region and dominant strategic location in the Middle East. Egypt became a US ally in 1979 when it signed a peace accord with Israel in Camp David over the displeasure of the Arab League and Organization of Islamic Countries (OIC). ${ }^{3}$ It continued to maintain close relations with the US and also joined its war against terrorism. As a result, Egypt has received around $\$ 2$ billion assistance after signing the Camp David Accord. However, this figure declined gradually 1998-2009 (Sharp, 2011).

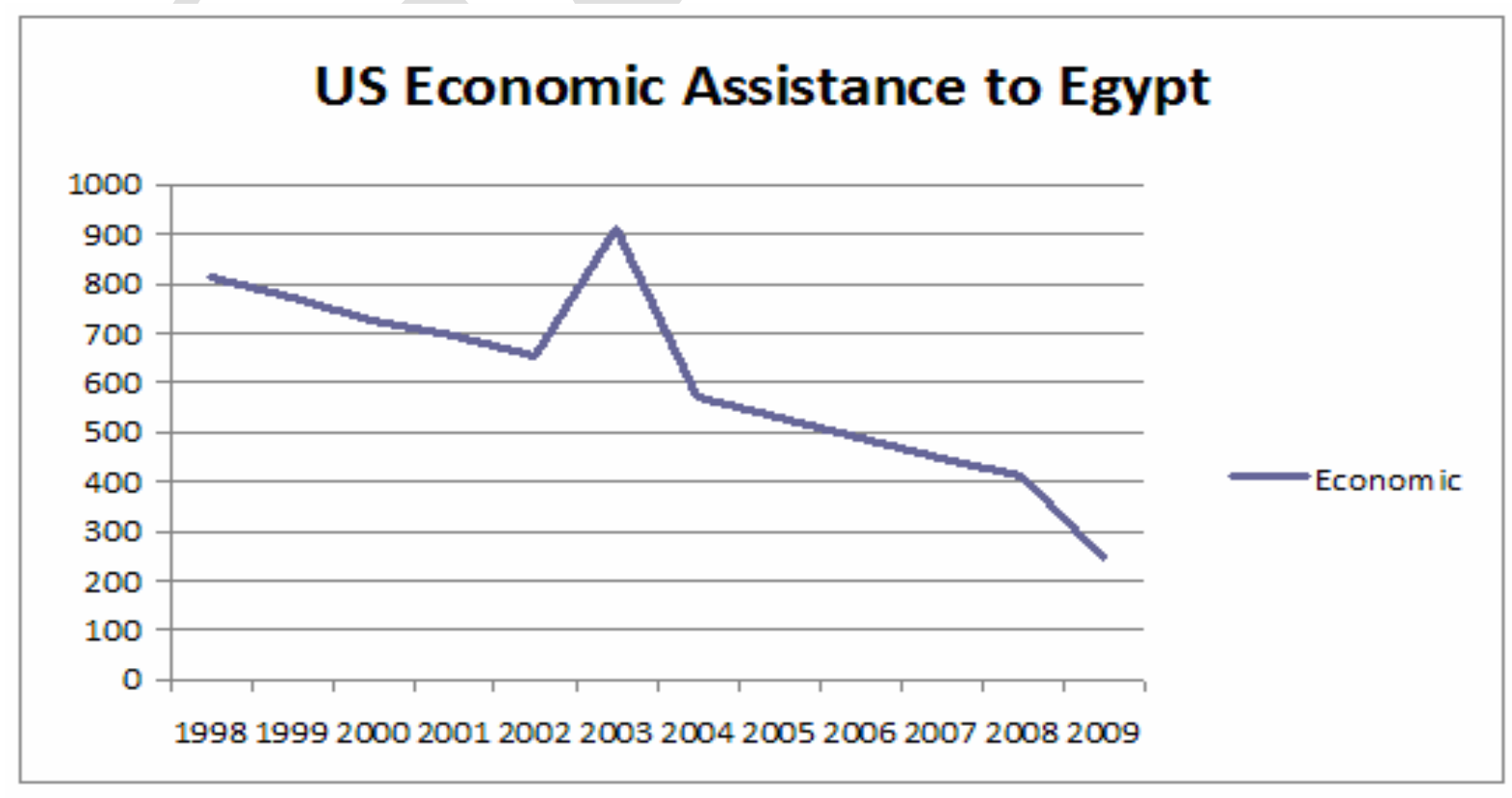


Another reason was the US support to NGOs and Civil Society, which promoted the antidictator political mobilization in one way and created resentment on the other. Although the US Secretary of State Collin Powell clearly warned while unveiling the program that "Any approach to the Middle East that ignores its political, economic, and educational underdevelopment will be built upon sand (Powell, 2002)," the US president Bush decided to withdraw US support to dictators in post $9 / 11$ era to address the causes of terrorism. He established the Middle East Partnership Initiative (MEPI) fund in December 2002, to support the US agenda of democratization. But the people of Egypt were fed-up with the dual policy of the US, supporting dictators and having cordial relations with the Egyptian military on one hand and funding NGOs for supporting democracy on the other. The resentment was clear as a Gallup Report (2012) reveals that Egyptian preferred to accept aid from Arab countries rather than that from US. While 86 percent men and 72 percent women were against US aid to civil society. However, they have accepted the importance of the electoral process to have a peoples' representative government, the need of human rights, end of discriminations and suppression by the government (Gallup Report, 2012).

\section{The Post-2011 Political Dynamics in Egypt}

Following the resignation of Mubarak, the Supreme Council of Armed Forces (SCAF) presided by Field Marshal Mohamed Hussein Tantawi, took the command of the country (Schenker, 2012). People were frustrated, raising slogans 'for dignity, democracy and social justice' during the mass protest. The first parliamentary elections in the post-revolution period were conducted under SCAF in 2011-2012. Before elections Muslim Brother (MB) renounced its policy of using violence. As a result it secured 45 percent of the seats in lower house of the parliament. Its presidential candidate Morsi, also won the election with a narrow margin against Ahmed Shafik, the former minister for civil aviation in Mubarak regime (Marwa, 2012). However, the judiciary did not allow the elected government to complete its term and adverse judicial decisions proved rampant shocks for the newly emerged political system. It declared newly elected parliament as illegitimate (Ahram, 2013).

SCAF prepared an interim constitution which was imposed on 17 June 2012. Later, the elected president Morsi presented his constitution on 26 December 2012. The government claimed that constitution was approved by 68.8 percent vote, but since the turnout was only 32.9 percent of the total eligible voters, the actual percentage of voters' support to decision was only 20.1 percent. The inexperience government of MB could not understand the demand of the people who wanted less powerful executive in a new system. Consequently, all the opposition parties started protesting to rescind extraordinary powers of the president. The mass protest and army's brutal crackdown on the protesters compelled the president to call for a referendum (Nazemroaya, 2013).

The first civilian president Morsi, ${ }^{4}$ failed to ensure the fundamental rights and tackle the economic crises. Military took this opportunity and given him forty-eight hours to deal with situation failing which he was dismissed from his office on $3^{\text {rd }}$ June 2013. The other difficulty was the new constitution of Egypt. Morsi remained in office just for one year and was dismissed after the series of strikes and protests by National Salvation Front, Al-Nour and anti-Islamists forces. ${ }^{5}$ After the dismissal of Morsi, SCAF captured the interim Government once again (BBC News, 2012). After just two years of mass mobilization, Egypt had been divided into four factions: SCAF supported by Judiciary; MB and its political wing 'the Freedom and Justice 
Party' (FJP); young liberals organized in a non-Party movement like 'April 6 Youth movement' and 'National Association for Change;' and the remnants of the previous regime (Baron, 2012). Other minor groups were also in line to secure their interests in new arrangement of power including Coptic Christians, which comprise around 8-12 percent population and Salafis that secure 21 percent seats in parliamentary elections of 2012 (Sharp, 2012).

The present shape of political system in Egypt shows that it has neither completed its transition to democracy nor it was heading towards it. The military continued to exist as a potent force, especially when the Morsi government called them in a manner as Mubarak regime used to call them to deal with the public protest. It has also renewed the emergency laws of Mubarak period. Judges appointed by the Mubarak regime gave verdicts averse to the spirit of public mandate and dismissed the Parliament. The President instead of calling for immediate elections postponed them on the account of political unrest. The Muslim Brother has lost its initial position due to its unpopular policies and backing out of initial commitments. Three of its offices were burnt by the protesters. Opposition groups and minority groups has been constantly protesting (Press TV, 2013). They claim that all the government machinery of Mubarak time was continuing in office and there was a status quo despite three years has gone to revolution. Economy was still running on aid from guidance of international organizations and Morsi's government has failed to take any measure to establish it on Islamic lines and provide social justice to the people.

One of the major reasons for derailment of the process of transition was an undemocratic role of judiciary. During the last 60 years, Egypt could have never established an independent Judiciary. The first pertinent clash between the judiciary and regime labelled as the "massacre of judge in which 100 judges were discharged. These judges had who had demanded the political reforms in 1969 under Gamal Abdul Naser (IBAHRI, 2011). Another division has been seen among judges based on political reasons, Islamic inclination, and ideological orientation (Pioppi, 2013). Generally, the judicial system of Egypt has never met with international criteria of an independent judiciary (Brown, 2012). What Egypt required was the change in all three fields: politics, economy, and security. Society has been getting polarized based on 'civil liberties, individualism, Islamism and secularism,' and the nature of change is still far from predict (UNDP, 2011).

Muslim Brother under Morsi failed to address these issues and convert their democratic aspirations into reality. Since the dismissal of Morsi in July 2013 further degenerated the situation of human rights since General Sisi came into power. He took drastic actions, which were adverse to all democratic norms. The most precarious incidents were: the detention of journalist on dubious charges, Minaya trial (BBC MEN) ${ }^{6}$, over 1500 Islamists were imprisoned along with Morsi and Rabaa massacre (Kingsley, 2014). ${ }^{7}$ Despite committing various atrocities, many people still view "the army (SCAF) as the safety net which protects Egypt from descending into total chaos (Cachalia, 2014)."

Political developments in the later months of Morsi's dismissal included a referendum to establish new constitution and presidential election. Nonetheless, the result of the 2014 elections were already certain as military steadfastly grabbing power since SCAF dismissed Morsi. The old guards of Egypt took over the power again with the same zeal and zest. Many of them believed to put Islamists behind the bars for political strife. However, the US insisted to allow the MB to participate in politics. Apparently, the military junta agreed but majority of 
them were not ready to sit with MB since they believed that MB has been involved in mass killings (The Guardian, 2013).

\section{The Implications of the Rise and Fall of Islamists in Egypt for Regional Politics}

The rise of Islamist power in Egypt stimulated the rise of Islamic parties in all the Middle Eastern Muslim states. They have leading roles in post-revolution Tunisia and Libya. In Syria and Yemen they have a key role in uprisings. Islamic parties have also won elections in Morocco and Kuwait. The rise of Islamist movements in the Arab countries that have passed through political upheavals over the last three years has become disconcerted now. Some of the pessimists were of the view that the "Arab Spring" has paved the way to an "Islamic Winter (Lynch, 2012)." They think that the dictators are replaced by religious fanatics. However, it is too early to lament on the issue.

The Islamist movements were having a long history of struggle. Their success was not a surprise. Since they have been reshaping the culture of the Arab lands for decades, and have long been the most popular and organized movements in their respective countries. The alternative intervals of tolerance and suppression towards the MB by the Egyptian dictators tell the story of their resistance to the later. In this process small faction of Islamist movements resorted to violence, while others have learned to address the political problems through political actions. At the time of the revolution Islamist, movements were well positioned to get "advantage of political openings and have indeed taken the lead in many of the transitions" (Ismael \& Ismael, 1985). In the first decade of the twenty-first century, they took the momentum to defend their faith and implement their political agenda against discrimination and Global War on Terror (GWOT).

There has been a steady growth of formidable political movements like the MB in Muslim countries wherever they got space to operate. It's a valid question that how would they shape or be shaped by the new politics of the region? In fact, rise of MB gave strength to the Muslim movements to fight with the despotic rulers in Yemen, Syria and Bahrain. The support these movements could get from the overwhelmingly Muslim population was not possible for any secular movement. The domino effect of the Iranian Revolution, which inspired these movements, but was curtailed by the unfavourable circumstances got time ripe for the change due to mass uprising. Although it was not a democratic start but keeping the experience of the European political parties, it looks that the Islamic movements would shape their politics on democratic norms as the only way to elevate themselves to the pedestal of governance (Aclimandos, 2010).

The second effect of the rise of Islamist in western perception was the rise of religious intolerance in the society against the minorities. That is already there and in transition period, it might be aggravated. Not only the religious but the sectarian differences have already been used by the dictators to divide the people. However, it would be confined to minor incidence of violence, not to the level of mass violence, because the Islamic parties, which rose to power, are those enjoying the reputation of moderate parties not the extremist one. The Sunni MB showed a positive gesture towards Shi'a Iran, ideologically a pole apart from each other, Morsi's official visit is the evidence of it. Despite all that the Iran-Saudi rivalry continued to plague the peace in Muslim countries. 
The third is the implication of rise of Islamists on Arab-Israel relations. Since the Hamas is close to the MB, therefore it was expected that Egypt would back out from Camp-David accord, 1979. But in the initial stages the declaration of SCAF to continue to honour Egypt's international commitment, was taken as a sign of relieve (New York Times, 2012). Morsi's reluctance to open Gaza's border was criticized, but it shows that the regional security was not likely to change.

Although Muslim Brotherhood does not support the idea of western styled democracy but it failed to please the counterrevolutionary forces and implement its political ideology and methodology. Consequently, it has been overthrown with the help of western supported factions and a military backed government under General El-Sisi has been established. MB along with its political wing Freedom and Justice Party was banned to participate in the 2014 elections. It has been officially declared a terrorist organization with violent ideology and pro MB protesters were extensively and publicly targeted (Al-Jazeera, 2014). All the modern Islamic movements were labelled as extremists by the western media. The whole Arab region was at risk of chaos since the followers of west appalled against the transitional phase of democracy and imprisoned thousands of Islamists. It was certainly a result of western fears and not a direct effect of MB's ideology (Monitor, 2014).

\section{The Response of the Western World towards Islamists Power}

Although the process started much before, but the way Tahrir Square demonstrations were staged in Egypt, it astonished the whole world. The volume of the protest with the representation of all the factions of the society attracted public opinion and policy makers from all around the world. In order to understand the response of regional and international community, it was important to consider their normative and materialist concerns in Egypt. As Amanda Dugan mentioned that state (Egypt) obtained negative as well as positive signals after the coup from the international community and it was a matter of their normative and materialist concerns of the international community. Positive signals indicate the support, whereas negative signals indicate the disapproval to the power shift/transition to Islamists (Shannon et al., 2014).

United States and its western allies were very optimistic about the people's uprising against the despotic rule. Especially the US policy makers were confident that it was the fruit of intellectual and fiscal investments of the US government in post 9/11 period (Bush, 2002). Therefore, they welcomed and appreciated the mass mobilization and the expectation mounted for the establishment of new democratic institutions. The rise of Islamists party to the pedestal of governance in Egypt eroded all optimism that the revolution could lead to the start of a new era in the Middle East. Later actions of the political government of MB further alarmed them about the future of democracy and sustainability of the fruits of the revolution. Two factors were responsible for this disappointment; the belief that elections might essentially lead to the establishment of western style of democracy; and the myth that the rise of Islamists parties would essentially lead to theocracy at once.

As Guazzone and Pioppi (2009) contends that the transformation did not really mean shift from an authoritarian regime to democracy. Western policy makers should understand that democracy has number of varieties. The intellectual debate in post-Karl Marx period was centred on the establishment of a more representative democracy that can address the 
apprehensions of all factions of the society rather than to protect the interests of a particular class. The concept of liberal democracy needs structural adjustments according to the culture and religion of the host society. No system of government can be successful without taking these factors into account. The inauguration of the MB in the corridors of power did not mean that the revolution has been failed. In fact, it had achieved half of the objective: it got rid of the decades' old despotic rule. Secondly although it could not put a lid to Military's desire to control the politics of the country. The rest half of the objective was the establishment of a more representative government with better ability to address economic and social problems of the state. It did not mean that these reforms eradicate the role of religion in the society and politics. However, the fear of regional; and international forces strengthened the old structures, military and judiciary to undo such democracy that could lead to Islamist government, detrimental to Israeli interests in Middle East.

In fact, the religion has penetrated in Muslim societies, more than ever. The rise of Islamist parties in Egypt is due to four factors. Firstly, Western support to despotic rulers in Arab lands who were fitted in their Cold War designs, counter to the peoples' interests. Western values of human rights, right of self-determination and plural democracy was compromised at the altar of superpower politics. Second factor was the Iranian revolution. Nonetheless, two poles apart on ideology, the Sunni Middle East became greatly inspired with the establishment of Shi'a Islamic order in Iran to get rid of the influence of both superpowers, the US and USSR. It stimulated the Islamic Movements as a domino effect.

The third factor which contributed was GWOT which is widely perceived as a war against Islam. The US invasion of Iraq and later in Afghanistan increased anti-Americanism and strengthened the need of awakening based on Islamic identity to save targeting of Muslim countries one after another. The theories of clash of civilization and the end of history presented by the Western scholars were also interpreted as the threat to the survival of the Muslim World. Though most of the Islamic countries were the US allies in GWOT, but the masses were against this war. This discontentment turned people into more practicing Muslims with the realization that Islam could be the only uniting force during resistance to the western political and ideological domination. Fourthly the world economic recession and collapse of the western banking system in twenty-first century contributed to the belief that Islam gives the best social, political, and economic system.

As far as the continental neighbour Europe's response is concerned, it is slightly relaxed as compared to that of the US. The Arab spring was a surprise to European powers. They were sceptical about the nature of Arab regimes in the post-revolution period. Keeping the Turkish model in view, one school of thought is optimistic about the change. They believed that the rise of Islamic political parties through electoral process is not a matter to worry. But the other school of thought considered the Iranian model and contended that Islamists might turn the system to a religious authoritarian system. Another fear of Europe was that Arab uprising might instigate extremists Muslims in Europe to start an uprising. The other fear was that if the Islamists imposed Islamic laws, then more secular factions and minorities might influx into Europe. The most important fear of the Europe was the Egypt-Israel relations. Even during the uprising, Europe was concerned about the security of its citizens on one hand and about the future of the Camp David accord on the other. This concern was responded by the SCAF within a few days of dismissal of Mubarak that the Egypt would continue to honour its international commitments (Anter, 2012). 
The EU transformed its European Neighbourhood Policy (ENP) with the new approaches for the protection of human rights and democratic values in response to the demonstrations all over the Arab world. The process of democratization remained central to the policy of the EU towards the Arab world. However, the optimism of EU, based on neoliberal values, failed in many Arab countries as the demonstrations triggered by the high unemployment rate and growing inequality. The rise of political Islam created problems for the normative policies of the EU because there is a contradiction between the policies of the EU and ideology of Islamic groups. EU' new strategy for Middle East can be defined in three points that are:

- Deep Democracy: The EU supports the process of democratization that requires the rule of law, freedom of expression and association and free and fair elections.

- People Partnership: The EU focuses to build a partnership with the civil society organizations and development sector of Egypt.

- Inclusive growth: Finally, the EU wants to attain inclusive growth amongst its partner countries which have been facing socioeconomic inequalities because socioeconomic equality is an imperative ingredient to introduce deep democracy.

The revision of the ENP presented an edge to address the key challenges in the Arab world at large (Behr, 2012). Catherine Ashton, the Foreign Policy Chief of the EU showed great concern in favour of Egyptians by stating that "The future of Egyptian people rightly remains in the hands of the Egyptian people." The main interest of the EU in Egypt is the Suez Canal which is quite crucial to access the oil. The EU continued to support Egypt under ENP in the area of energy and economy since 1995. In return, Egypt assures to follow the human rights and democratic norms of the EU. The EU supported Egypt to improve its economic competitiveness for the efficient utilization of natural resources. The EU played a key role as a mediator along with the United Nations (UN) and US for the political solution in internal strife in Egypt. However, all the efforts made by the US, EU and UN for the political solution broke down when approximately 900 people died and many more injured in the week followed by Morsi's dismissals (Al-Jazeera, 2014).

Sally Khalifa Issac, Professor of Economics and Political Science at Cairo University assumed that overall response of the EU to the revolutionary events in the Arab world was weak and hollow. The EU was likely hesitant to take any clear stance on public protests. Initially, they didn't demand the dismissal of Mubarak rather called for necessary reforms and end the atrocities against the peaceful demonstrations until the clear announcement by the US president Barak Obama that "Mubarak should leave now" (Isaac, 2012). There were various reasons behind the weak response of the EU, ranged from financial issues to strategic and security concerns in the Arab region.

The EU opened its "soft power strategy and new form of European diplomacy" to overcome the divisions in the Egyptian society. Some progress has been noticed in 2013 during the power transition period from military to civilian government, but the suspension of national Assembly and violation of human rights "pitched the nation into a divisive political crisis," coup d'etat became hurdle in the way of the EU to take any strong policy line (CEPS, 2013).

Essentially, Egypt needed to take a clear stance towards political reconciliation, constitutional reform and democracy and to support democratic norms is in the long and short term interests of the EU under ENP (Blocmans, 2012). The strategic position of Egypt, both politically and 
territorially important for the EU, as it is located in the southern neighbourhood that is why imperative to put in order its relation with the Mediterranean Countries. For them both Morsi or Mubarak regime didn't take any stance to tackle human rights violations etc.

The UN security council showed lack or almost no interest about the chaotic situation in Egypt and Tunisia. Ban Ki Moon, the UN Secretary General stated at the time of Mubarak's resignation that "I respect what must have been a difficult decision, taken in the wider interests of the Egyptian people" and spoke in favour of Arab people that it is the responsibility of leadership to 'care for their own people' (UN Press Release, 2011). Navi Pllay, the Chief of UN Human Rights Commission urged the government of Egypt to accommodate the viewpoint of all the opposing parties as a result of riots against Morsi and at the time of the second anniversary of the Egyptian 2011 revolution. She stressed to avoid the use of violence, enforcement of law and order and resolve their issues in a peaceful manner. Further, she asked Morsi in a meeting to hear the demands of protesters and opposition, address the major domestic issues and tackle their problems (UN News Center, 2013). However the UN could not take any practical measure to check political violence especially government action against MB workers after dismissal of Morsi government.

\section{Conclusion}

The ground realities need a better understanding about the social-political culture of these lands. Middle East is predominantly Muslim and it's a fact that in Muslim societies the religion cannot be separated from the state. Muslims have a strong role of religion in their private and public life. Therefore, whenever there will be elections in the Muslim world the role of religion will be there. The west needs to wait and give time to the democratic process take its natural pace and be ready to accept the Islamist variety of democracy, with some attributes of the western liberalism intermingled with Islamic values.

Masoud (2014) the author of Counting Islam, says that the failure of Egypt has less to do with its Islamist than political milieu. It is evident that even after three years of revolution, Egypt is in the ongoing process of transition. The nature and direction of change in Egypt is still not clear and society is polarized on the question of socio-political and economic performance of government. The internal security system has failed despite new laws introduced by Morsi regime to improve security situation. The socioeconomic and political structure of the country is unstable and secular and Islamist forces are unable to reconcile on one agenda. However, it is evident that people would not accept the dictatorial rule again.

The process of change in the Arab region is hampered by the weak political structures, inefficient judicial/legal system, lack of institutional mechanism, and competition between Islamist and liberal forces. In order to resolve unrest and chaos, what Egypt requires is: to activate civil society, rational decision making, political will to bring the Islamist and secular forces at one agenda, and negotiate a viable solution to existing problems through a national debate. In all that process military and judiciary should go back to their original role as security apparatus and responsible for justice respectively. Their engagement with politics is a major threat to democratic process in Egypt, if there is any. It was also evident from the speech of General Abdell Fattah El-Sisi, head of post-Morsi government, clearly stated to appease religious sentiments of the people while addressing the Imams of Egypt that "we are in need of religious revolution and you Imams are responsible in front of Allah" (Ford, 2015). 


\section{References}

Al-Jazeera (2014, March 08). Egypt's military cements its power. http://www.aljazeera.com/indepth/features/2014/03/egypt-military-cements-powersisi-scaf-201436112337615533.html

Anter, B. N. A. (2012). Europe and Islamists' ascension to power in neighbouring ArabMediterranean countries. Report of Al Jazeera Centre for Studies. http://studies.aljazeera.net/ResourceGallery/media/Documents/2012/1/29/20121299 423770580Europe on 05/14/13.

Arab Spring. (2011). United Nations Development Project (UNDP). https://www.ucdp.uu.se.

Ahram (2013, April 14). Egypt Court Delays Verdict on Parliamentary Elections. http://english.ahram.org.eg/NewsContent/1/64/69 182/Egypt/Politics-/Egypt-courtdelays-verdict-on-parliamentary-electi.aspx

Baron, L F. (2012). More than a Facebook revolution: Social movements and social media in the Egyptian Arab Spring. International Review of Information Ethics, 18.

BBC News. (25 June 2012). Mass Egypt death sentences 'breach International law'. BBC Middle East. http://www.bbc.com/news/world-middle-east-26726901

Behr, T. (2012). After the Revolution: The EU and Arab transition. Notre Europe. https://institutdelors.eu/wpcontent/uploads/2020/08/eu_arabtransition_t.behr_ne_april2012.pdf

Beitler, R. M. (2003). Egypt as a failing state: Implications for US national security. DIANE Publishing.

Blocmans, S. (25 June 2013). Egypt and the EU: where next? https://www.ceps.eu.

Brown, N. J. (2012). When victory becomes an option Egypt's Muslim Brotherhood confronts success. Carnegie Endowment for International Peace. http://carnegieendowment.org/files/brotherhood_success.pdf

Bush. G W. (2002). State of the Union Address.

Cachalia, C. (2014). Egyptian election 2014: in the midest of democracy or autocracy? Consultancy Africa Intelligence (CAI). http://www.consultancyafrica.com/index.php?option=com_content\&view=article\&i $\mathrm{d}=1685$ :egyptian-election-2014-in-the-midst-of-democracy-orautocracy\&catid=42:election-reflection \&Itemid $=270$

Calleya, S.C., \& Wohlfeld M. (2012). Change and opportunities in the emerging Mediterranean, (pp. 54-68). Malta: Gutenberg Press.

CEPS, European Neighborhood Watch. (2013). Egypt and the EU: What next? Issue No. 98. http://viktorvoksanaev.blogspot.com/2013/11/ egypt-and-eu-what-next.html

De Smet, B., \& Matthies-Boon, V. (2013). Egypt: from rebel to revolution? Open Democracy. https://www.opendemocracy.net/brecht-de-smet-vivienne-matthies-boon/egyptfrom-rebel-to-revolution.

Ford, D. (2015, January 6). Egypt's President calls for a 'religious revolution. CNN International. http://edition.cnn.com/2015/01/06/africa/egypt-president-speech/.

Gallup Report. (2012). After the Arab Uprisings: Women on rights, religion, and rebuilding.

Glassman, J. K., \& Glickman, D. (2011). Strategic Public Diplomacy: The Case of Egypt. national security project, October. http://bipartisanpolicy.org/library/report/strategic-public-diplomacy-case-egypt.

Guazzone, L., \& Pioppi, D. (2009). Interpreting change in the Arab world. The Arab State and Neo-Liberal Globalization: The Restructuring of State Power in the Middle East, 115. 
Holding its breath: A special report on Egypt. (2010). No. 8. The Economist.

Human rights first, fact sheet. (2011) United States Commission on International Religious Freedom (USCIRF). $\quad$ http://www.humanrightsfirst.org/wpcontent/uploads/pdf/Fact_Sheet-Egypt-Sectarian-Violence.pdf.

International Bar Association's Human Rights Institute (IBAHRI). (2011). Justice at crossroads: The legal profession and the rule of law in the new Egypt. file:///C:/Users/SADIA/Downloads/Egypt\%20report\%20(Nov\%202011)\%20(2).pdf

Isaac, S. K. (2012). Europe and the Arab Revolutions-From a Weak to a Proactive Response to a Changing Neighborhood (No. p0039). Free University Berlin. http://userpage.fuberlin.de/kfgeu/kfgwp/wpseries/WorkingPapperKFG_39.pdf

Ismael, T. Y., \& Ismael, J. S. (1985). Government and politics in Islam. Pinter.

Aclimandos, T. (2010). Islamist Mass Movements, External Actors and Political Change in the Arab World. Cespi Report

Kingsley, P. (2014). Egypt's Rabaa massacre: one year on. The Guardian,16. http://www.theguardian.com/world/2014/aug/16/rabaa-massacre-egypt-humanrights-watch

Lynch, M. (2012). Islamists in a changing Middle East. Foreign Policy. http://www.foreignpolicy.com/files/042ff47cd92e3ca8a4bc92e94b 3f6ccc.pdf

Londono, E. (2011). Egyptian man's death became symbol of callous state. Washington Post, 9. http://www.washingtonpost.com/wpdyn/content/article/2011/02/08/AR2011020806 360.html.

Masoud, T. (2014). Counting Islam: Religion, class, and elections in Egypt. Cambridge University Press.

Monitor, M. E. (2014). a. The Muslim Brotherhood and Salafist Jihad (ISIS): Different Ideologies, Different Methodologies. Middle East Monitor.

Nazeroaya, Darius Mahdi. (22 January 2013). Egypt's constitutional referendum: Did President Morsi hijack democracy? http://www.globalresearch.ca/statisticallyexamining-cairos-constitutional-referendum-did-morsi-hijack-democracy/5320067

New York Time (2012, August 11). President Morsi's first crisis. http://www.nytimes.com/2012/08/11/opinion/president-morsis-firstcrisis.html? $\mathrm{r}=0$

Pioppi, D. (2013). The Judiciary and Revolution in Egypt. Insight Egypt, 2, 1-7. https://unora.unior.it/retrieve/handle/11574/119215/3816/inegypt_02.pdf

Plumer, B. (2013). The economic roots of Egypt's crisis. The Washington Post. https://www.washingtonpost.com/news/wonk/wp/2013/07/03/the-economic-rootsof-egypts-crisis/

Powell, C. L. (2002). The US-Middle East Partnership Initiative: Building Hope for the Years Ahead. Heritage Foundation.

Press TV (27 May 2013). Egypt' Morsi expect Parliamentary elections for October. http://www.presstv.com/detail/2013/03/27/295379/egypt-plans-parl-elections-foroctober/

Schenker, D (2012). The revolution in Egypt: Turning point. The Washington Institute for Near East Policy. http://www.washington institute.org/uploads/Documents/testimony/SchenkerTestimony,20120620.pdf.

Shannon, M., Thyne, C., Hayden, S., \& Dugan, A. (2015). The international community's reaction to coups. Foreign Policy Analysis, 11(4), 363-376. https://doi.org/10.1111/fpa.12043 
Sharp, J.M. (2011). Egypt in Transition. CRC Report for Congress. https://www.everycrsreport.com/files/20110823_RL33003_21b7aff0b3454409a2b4 f2de102012c5c2645041.pdf

Sharp, J.M. (2012). Egypt: Transition under military rule. CRC Report for Congress.

Social Capital Blog. Updated. (8 May 2013). http://socialcapital.wordpress. com/2011/01/26/twitter-facebook-and-youtubes-role-in-tunisia-uprising/

Taylor, K. (2011). Arab Spring really was social media revolution. TG Daily, 13. http://www.tgdaily.com/software-features/58426-arab-spring-really-was-socialmedia-revolution.

UN News Center. (2013). UN rights chief urges talks to save Egypt from further disastrous violence. http://www.un.org/apps/news/story.asp?NewsID=45628\#.VKUEndKUewI

UN Press Release. (2011, February 11). In Wake of Egyptian President Hosni Mubarak's Resignation, Secretary-General Commends Egyptian People for Courageous Exercise of Their Legitimate Rights. SG/SM/13400. http://www.un.org/press/en/2011/sgsm13400.doc.htm.

\section{Notes:}

${ }^{1}$ In 2005survey in Egypt told that 87 percent of citizens that take religion as the most important aspect of their identity. Quoted in Ferry de Kerckhove, "Egypt's Muslim Brotherhood and the Arab Spring," May 2012, Policy update paper, Canadian Defence and Foreign Affairs Institute. Gallup poll 2012 revealed that 50 percent men and 44 percent women believed that Sharia should be the only source of legislation in Egypt.

${ }^{2}$ He was a young street grocery vendor who set himself on fire on 17, December 2010 and died on 4 January as a protest against a corrupt and autocratic system. Just 10 days after his death, President Ben Ali's 23 yearlong rule of Tunisia came to end. Rania Abouzeid, "Bouazizi: The Man Who Set Himself and Tunisia on Fire" 2011, January 21 http://www.time.com/time/magazine/article/0,9171,2044723,00.html\#ixzz2TEu8xEEx

3 It was expelled from the membership of both organizations as a punishment.

${ }^{4} \mathrm{He}$ was first elected president of Egypt but fifth in order since Gamal Abdul Nasir.

5 The National Salvation Front (NSF) is an opposition coalition formed amid the recent political crisis which has engulfed Egypt. The NSF includes a wide range of liberal, secular and leftist groups, such as the Egyptian Popular Current, al-Dustour, al-Tajammu, Free Egyptians, New Wafd, Democratic Front, the Egyptian Social Democratic Party, Nasserist Democratic Party and the Conference Party.

${ }^{6}$ In Minaya trial, 529 people were killed in a first mass trial, alleged attack on police station in Minaya. After a few days 683 Morsi supporters went on trial by the same court and the third mass trial was given to 919 Islamist on the charges of murder despite strong criticism by human rights activists.

${ }^{7}$ In Rabaa massacre, approximately 1000 pro Morsi protesters were killed, over 800 arrested and thousands injured at al Nahda and Rabaa al- Adwiya squares by the military backed government of SCAF. 